\title{
Penerapan Media Gambar Berseri untuk Meningkatkan Kemampuan Berbicara Anak Usia Dini Pada Kelompok B TK Permata Bunda Banda Aceh
}

\author{
Israwati ${ }^{1}$, Rosmiati $^{1}$, Putry Julia ${ }^{2}$, Irma Yana $L^{1}$ \\ Fakultas Keguruan dan Ilmu Pendidikan Universitas Syiah Kuala ${ }^{1}$ \\ Fakultas Keguruan dan Ilmu Pendidikan Universitas Serambi Mekkah ${ }^{2}$ \\ Email. israwati@unsyiah.ac.id, irmayanalimbong@gmail.co.id
}

\begin{abstract}
Abstrak
Kecerdasan berbicara merupakan kecakapan mengucapkan bunyi-bunyi artikulasi atau kata-kata yang mengekspresikan, menyatakan, serta menyampaikan pikiran, gagasan dan perasaan. Penelitian ini bertujuan untuk mengetahui kemampuan berbicara anak usia dini menggunakan media gambar berseri di kelompok B TK Permata Bunda Banda Aceh. Penelitian ini menggunakan metode penelitian tindakan kelas yang dilakukan dalam 2 siklus. Pada setiap siklus terdapat 4 tahapan yaitu perencanaan, pelaksanaan, observasi dan refleksi. Subjek penelitian ini adalah anak usia dini pada kelompok B TK Permata Bunda Banda Aceh tahun ajaran 2018/2019 berusia 5-6 tahun yang berjumlah 12 orang anak. Data penelitian dikumpulkan melalui observasi dan unjuk kerja. Hasil penelitian menunjukkan bahwa pada tindakan prasiklus 8 orang anak $(66,7 \%)$ yang belum berkembang, mulai berkembang 4 orang anak $(33,3 \%)$. Sedangkan anak pada kategori berkembang sesuai harapan dan kategori berkembang sangat baik belum ada. Pada tindakan siklus I anak pada kategori belum berkembang ada 3 orang anak (25\%), mulai berkembang ada 5 orang anak $(41,7 \%)$. Pada kategori berkembang sesuai harapan ada 4 orang anak $(33,3 \%)$, sedangkan anak yang berkembang sangat baik belum ada. Pada tindakan siklus II tidak ada lagi anak yang belum berkembang. Kategori mulai berkembang berjumlah 2 orang anak (16,7\%). Berkembang sesuai harapan ada 6 orang anak (50\%), dan berkembang sangat baik 4 orang anak $(33,3 \%)$. Pada tindakan siklus II menunjukkan bahwa persentase anak mendapatkan bintang 3 dan bintang 4 mencapai angka lebih dari $80 \%$. Disimpulkan bahwa melalui media gambar berseri dapat digunakan untuk meningkatkan kemampuan berbicara anak usia dini. Disarankan bagi guru dalam meningkatkan kemampuan berbicara anak usia dini dapat dilakukan melalui media gambar berseri, baik dalam mengenalkan tema maupun menyampaikan ceritacerita berseri lainnya.
\end{abstract}

Kata Kunci : Berbicara, Anak Usia Dini, Media, Gambar Berseri

\section{PENDAHULUAN}

Masa emas tumbuh kembang seorang anak, bukan hanya fisiknya tetapi juga kognitif, social emosional dan jiwanya. Pada masa ini terdapat potensi dan aspek-aspek perkembangan anak yang sebisa mungkin harus dirangsang diantaranya perkembangan kognitif, perkembangan sosial-emosional, perkembangan fisik motorik, perkembangan moral agama dan juga perkembangan bahasa.

Pada hakekatnya setiap anak merupakan anak yang cerdas.Gardner melihat kecerdasan dari berbagai dimensi, sebagaimana yang dinyatakan oleh Gardner (Yus, 2011) kecerdasan terdiri dari berbagai dimensi. Dimensi pertama yaitu kecerdasan logika matematika berkaitan dengan keterampilan dan persepsi dalam bidang angka. 
Dimensi kedua kecerdasan musik berkaitan dengan keterampilan dan persepsi dalam bidang musik dan suara. Dimensi ketiga kecerdasan kinestetis berkaitan dengan keterampilan dan persepsi dalam bidang mengolah dan mengendalikan gerak anggota tubuh. Dimensi keempat kecerdasan visual-spasial berkaitan dengan keterampilan dan persepsi dalam bidang permainan garis, warna bentuk, dan ruang. Dimensi kelima kecerdasan intrapersonal berkaitan dengan keterampilan dan persepsi dalam bidang pengenalan terhadap diri sendiri. Dimensi keenam Kecerdasan interpersonal berkaitan dengan keterampilan dan persepsi dalam bidang membina hubungan dengan orang lain. Dimensi ketujuh kecerdasan naturalis berkaitan dengan keterampilan dan persepsi dalam bidang yang berhubungan dengan alam dan lingkungan sekitar, dan dimensi yang terakhir yaitu kecerdasan bahasa (linguistik) berkaitan dengan keterampilan dan persepsi mengelola kata dan bahasa.

Pada usia 5-6 tahun perkembangan bahasa anak sudah mendekati kesempurnaan. Kosakata anak terus berkembang dan anak mulai memahami bahwa kata-kata memiliki lebih dari satu arti. Papilla dan Olds (Surna, 2014) mengemukakan bahwa anak usia 6 tahun mampu menggunakan kata-kata sebanyak 2600 kata dalam percakapan dan memahami lebih dari 20.000 kata. Idealnya anak usia 5-6 tahun menurut Permendikbud tentang Standar Nasional Pendidikan Anak Usia Dini No. 137 Standar Tingkat Pencapaian Perkembangan Anak pada aspek bahasa usia 5-6 tahun salah satunya "anak sudah mampu mengekspresikan bahasa, mampu bertanya, menjawab pertanyaan, berkomunikasi secara lisan, menceritakan kembali yang diketahui, belajar bahasa pragmatik, mengekspresikan perasaan, ide dan keinginan dalam bentuk coretan.

Bahasa anak usia dini dapat dikembangkan melalui tiga jalur pendidikan yaitu, pendidikan informal, non formal, dan formal. Pendidikan informal dapat ditemukan pada homeschooling, Pendidikan Anak Usia Dini (PAUD) atau Satuan PAUD Sejenis (SPS) pada jalur non formal, dan pendidikan di Taman Kanak-kanak (TK) pada jalur formal (Sanjaya, 2009). Pada usia dini pengembangan bahasa sangat penting karena masa usia dini merupakan masa peka.

Kemampuan Berbicara merupakan suatu kemampuan dan kemampuan tidak akan berkembang jika tidak dilatih secara terus menerus. Oleh karena itu, kemampuan berbicara pada anak tidak akan dikuasai dengan baik tanpa dilatih. Apabila selalu dilatih, kemampuan berbicara tentu akan semakin baik. Sebaliknya, kalau malu, ragu, atau takut salah dalam berlatih berbicara, niscaya kemampuan berbicara lebih mudah dikembangkan apabila anak memperoleh kesempatan untuk mengkomunikasikan sesuatu secara alami kepada orang lain.

Berdasarkan hasil observasi dan pengalaman peneliti sebagai guru magang pada kelompok B di Lembaga TK Permata Bunda Kota Banda Aceh, ditemukan perkembangan bahasa khususnya kemampuan berbicara belum berkembang secara optimal dan masih memerlukan peningkatan. Hal ini dibuktikan dengan adanya sebagian anak belum mampu mengungkapkan ide menggunakan kalimat sederhana. Kelompok B TK Permata Bunda terdiri atas 25 anak, beberapa anak yang dapat mengungkapkan ide menggunakan kalimat sederhana, terdapat 12 orang anak yang kurang lancar dalam menyampaikan ide dan suara masih pelan ketika berbicara. Hal ini terlihat dalam proses pembelajaran saat guru meminta anak untuk menceritakan gambar, anak membutuhkan waktu jeda yang terlalu lama yaitu sekitar 15 sampai 20 detik untuk menceritakan gambar. Selain itu, anak hanya mengungkapkan 1-2 kata dan 
ekspresi yang ditunjukkan kurang berani menyampaikan pendapatnya serta malu untuk bertanya. Selain permasalahan tersebut, penggunaan media pembelajaran juga belum maksimal sehingga hal tersebut mempengaruhi ketertarikan anak dalam mengikuti proses pembelajaran.

\section{TINJAUAN PUSTAKA}

Joyce (dalam Trianto, 2009) mengatakan "model pembelajaran mengarahkan kita ke dalam mendesain pembelajaran untuk membantu peserta didik sedemikian rupa sehingga tujuan pembelajaran tercapai”. Pembelajaran di Taman Kanak-kanak berlangsung secara maksimal apabila ada media yang mendukung dalam proses pembelajaran. Menurut Sadiman (2009), kata media berasal dari bahasa latin dan merupakan bentuk jamak dari kata medium yang secara harfiah berarti perantara atau pengantar.

Menurut Enoch (dalam Hairuddin, 2007) "penggunaan media dalam proses belajar mengajar dapat mengakibatkan motivasi dan rangsangan dalam proses belajar mengajar, serta dapat mempengaruhi psikologis siswa". Menurut Zaman dkk (2007) "peran media dalam pembelajaran di Taman kanak-kanak semakin penting mengingat perkembangan anak pada saat ini berada pada masa konkret". Prinsip kekonkretan tersebut mengisyaratkan perlunya digunakan media sebagai saluran penyampai pesan dari guru kepada anak didik agar pesan/informasi tersebut dapat diterima atau diserap anak dengan baik.

Kemp dan Dayton (dalam Hairuddin, 2007) mengidentifikasi beberapa manfaat media dalam pembelajaran yaitu yang pertama penyampaian materi pelajaran dapat diseragamkan. Kedua proses pembelajaran menjadi lebih jelas dan menarik. Ketiga proses pembelajaran menjadi lebih interaktif. Keempat pemakaian waktu dan tenaga lebih efisien. Kelima kualitas hasil belajar siswa meningkat. Keenam proses belajar dapat dilakukan di mana saja dan kapan saja. Ketujuh menumbuhkan sikap positif siswa terhadap proses belajar. Kedelapan mengubah peran guru kearah yang lebih positif dan produktif. Salah satu media yang dapat digunakan untuk meningkatkan kemampuan berbahasa lisan anak adalah media gambar berseri.

Media gambar merupakan media visual. Media visual adalah media yang dapat menyampaikan pesan/informasi secara visual. Artinya penerima pesan yaitu anak didik akan menerima informasi melalui indera penglihatan, karena pesan yang akan dituangkan ke dalam simbol-simbol komunikasi visual (Dhieni dkk, 2005). Sadiman (2002) mengemukakan bahwa "gambar adalah media yang paling umum dipakai dan merupakan bahasa yang umum, yang dapat dimengerti dan dinikmati di mana-mana serta gambar dapat mengatasi batasan ruang dan waktu".

Syarat-syarat memilih media gambar yang baik (Dhieni dkk, 2005) adalah pertama perlu diperhatikan keaslian gambar, artinya gambar menyerupai benda aslinya baik bentuk dan warna. Hal ini untuk menghindari agar tidak terjadi kesalahpahaman. Kedua gambar yang digunakan hendaknya memenuhi syarat kesederhanaan, yaitu gambar tidak rumit karena anak lebih menyukai gambar yang sederhana agar mudah ditanggapi. Ketiga gambar yang baik adalah gambar yang dapat ditanggai dengan tepat tentang objek gambar, agar tidak terjadi kesalahpahaman. Keempat gambar hendaknya menunjukkan suatu perbuatan sehingga kelihatan hidup atau bergerak. Kelima gambar sebagai media pembelajaran hendaknya dipilih yang memiliki nilai fotografisrendah, agar mudah dipahami atau langsung dapat ditanggapi. Keenam gambar sebagai media 
juga hendaknya tidak terlalu artistik, karena yang dipentingkan bahwa sekedar indahnya saja tetapi makna yang terkandung di dalamnya dan mudah dimengerti.

Menurut Dhieni dkk (2005) kelebihan dari media gambar adalah gambar bersifat konkret, gambar mampu membatasi ruang, waktu dan kemampuan daya indera manusia, gambar dapat digunakan menjelaskan suatu masalah, baik yang bersifat konkret ataupun abstrak, gambar merupakan media yang mudah didapat dan murah, gambar juga mudah digunakan, baik secara individual, kelompok, klasikal, seluruh kelas atau sekolah. Sehingga pesan yang tersirat dalam gambar tersebut dapat dinyatakan kembali dalam bentuk kata-kata atau kalimat. Penerjemahan pesan dari bentuk visual ke dalam bentuk kata-kata atau kalimat sangat tergantung pada kemampuan imajinasi siswa.

Media gambar berseri sebagai media pembelajaran dalam kriteria pemilihan media bahwa media digunakan harus sesuai dengan taraf berfikir anak didik. Dengan melihat gambar, siswa dapat menarik isi kesimpulan dari gambar tersebut, kemudian dapat menguraikan dalam ungkapan. Dalam kriteria pemilihan media disinggung bahwa media yang digunakan harus sesuai dengan taraf berfikir anak didik. Dengan melihat gambar, siswa dapat menarik isi kesimpulan dari gambar tersebut. Penggunaan media gambar berseri anak mampu meningkatkan kemampuan berbahasa lisan (Ni Made, 2003).

\section{METODE}

Penelitian ini dilaksanakan di kelompok Blembaga TK Permata Bunda Kecamatan Syiah Kuala Kota Banda Aceh. Waktu penelitian dilaksanakan pada semester I tahun ajaran 2017/2018, mulai dari bulan September sampai dengan Oktober 2017.

\section{Subjek Penelitian}

Subjek penelitian ini adalah anak kelompo

k B lembaga TK Permata Bunda Kecamatan Jaya Baru Kota Banda Aceh yang berusia 5-6 tahun. Subjek penelitian berjumlah 12 anak yang terdiri dari 5 laki-laki dan 7 perempuan.

\section{Teknik pengumpulan data}

Teknik pengumpulan data dalam penelitian ini adalah observasi dan unjuk kerja.Observasi dilakukan oleh guru kelompok B TK Permata Bunda.

\section{Teknik analisis data}

Teknik analisis data yang digunakan adalah teknik analisis kualitatif (yaitu berupa kata-kata bukan data angka) dimana data yang diungkapkan dan dianalisis merupakan data yang berkaitan dengan kemampuan berbicara anak kelompok B TK Permata Bunda Kecamatan Syiah Kuala Kota Banda Aceh.

Adapun yang menjadi indikator kinerja untuk mengukur keberhasilan dalam penelitian ini adalah: 


\begin{tabular}{|c|l|l|}
\hline No & \multicolumn{1}{|c|}{ Aspek Perkembangan } & Kriteria Bintang \\
\hline 1. & $\begin{array}{l}\text { Belum berkembang (BB) anak belum mampu } \\
\text { mengungkapkan ide atau gagasan melalui gambar } \\
\text { berseri dengan baik, dengan bantuan guru. }\end{array}$ & $*$ \\
\hline 2. & $\begin{array}{l}\text { Mulai berkembang (MB) anak mulai mampu } \\
\text { mengungkapkan ide atau gagasan melalui gambar } \\
\text { berseri dengan bantuan guru. }\end{array}$ & $* *$ \\
\hline 3 & $\begin{array}{l}\text { Berkembang sesuai harapan (BSH) anak sudah } \\
\text { mampu mengungkapkan ide atau gagasan melalui } \\
\text { gambar berseri tanpa bantuan guru, tetapi masih } \\
\text { memiliki jeda yang lama saat mengungkapkan. }\end{array}$ & $* * *$ \\
\hline 4 & $\begin{array}{l}\text { Berkembang sangat baik (BSB) anak sudah mampu } \\
\text { mengungkapkan ide atau gagasan melalui gambar } \\
\text { berseri dengan baik dan tanpa jeda yang lama, tanpa } \\
\text { bantuan dari guru dalam mengungkapkan dan } \\
\text { mampu menjelaskan kepada temannya. }\end{array}$ & $* * *$ \\
\hline
\end{tabular}

Penelitian ini dikatakan berhasil jika memenuhi indikator yang ditetapkan. Adapun indikator yang ditetapkan.Sudjana (Dymyati 2013:15) menyatakan bahwa "batas ketuntasan secara klasikal dari hasil belajar anak adalah 75-80\%".

Berdasarkan pada tahapan prasiklus kemampuan berbicara anak pada kelompok B TK Permata Bunda masih belum berkembang dengan baik, sesuai yang diharapkan. Oleh karena itu, peneiti melakukan penelitian peningkatan kemampuan berbicara anak usia dini melalui media gambar berseri.

Setelah diberikan tindakan maka diperoleh hasil siklus Idapat dilihat kemajuan kemampuan anak melalui data yang diperoleh. Hasil penelitian setelah pelaksanaan proses pembelajaran melalui media gambar berseri untuk meningkatkan kemampuan berbicara anak usia dini pada tindakan siklus I menunjukkan adanya peningkatan hasil dibandingkan pengamatan pada prasiklus. Adapun jumlah anak yang belum berkembang menjadi 3 anak. Selanjutnya untuk kemampuan berbicara anak mulai berkembang (MB)menjadi 5 anak, dan untuk kemampuan berbicara anak berkembang sesuai harapan (BSH) menjadi 4 orang anak, sedangkan untuk kemampuan berkembang sangat baik (BSB) masih belum terlihat. Sedangkan pada hasil tindakan siklus I menunjukkan bahwa perkembangan kemampuan berbicara anak belum mencapai indikator yang ditetapkan. Pada kegiatan ini baru tercapai 33,3\% pada kategori bintang 3 (BSH) dan bintang 4 (BSB). Anak mulai dapat berkembang kemampuan berbicara mengemukakan pendapatnya maupun bertanya tentang gambar, anak juga sudah dapat mengikuti aturan yang disampaikan guru yang sebelumnya sudah disepakati bersama, namun masih ada 5 (MB) anak yang tidak mengikuti aturan ketika peneliti menceritakan media gambar berseri dan sebagian anak masih malu-malu dalam berbicara di depan teman-temannya masih dibantu oleg guru.Hasil siklus I ini dijadikan acuan dalam melakasana tindakan siklus II.

Selanjutnya Hasil pengamatan selama kegiatan yang berlangsung pada siklus II sudah dapat dilihat kemajuan kemampuan berbicara anak melalui data yang penelitianpada tahap pengamatan. Hasil pengamatan setelah pelaksanaan proses pembelajaran melalui kegiatan kemampuan bercerita menggunakan media gambar berseri untuk meningkatkan kemampuan berbiara anak usia dini pada siklus II 
menunjukkan peningkatan kemampuan berbicara seluruh anak telah berkembang sangat baik (BSB), sudah $100 \%$, dibandingkan pada hasil pengamatan pada siklus I.

Hasil penelitian menunjukkan bahwa peningkatan kemampuan berbicara anak dari prasiklus, siklus I dan siklus II dapat dilihat peningkatan berbicara anak melalui media gambar berseri. Efektivitas bercerita menggunakan media gambar berseri dapat meningkatkan kemampuan berbicara anak usia dini sejak dilakukan pada tahap prasiklus sampai dengan siklus II. Pada tindakan prasiklus kemampuan berbicara anak belum berkembang yaitu sebanyak 8 orang anak, dan pada siklusI anak belum berkembang kemampuan berbicara menjadi 3 orang anak pada siklus I, sedangkan pada siklus II kemampuan berbicara anak semuanya sudah berkembang sangat baik (BSB) dengan demikian tidak terlihat lagi anak dengan kemampuan bicara belum berkembangI. Selanjutnya pada tindakan prasiklus anak yang berkemampuan mulai berkembang yaitu dari 4 orang anak menjadi 5 orang anak pada siklus I, dan menjadi 2 orang anak pada siklus II. Kemudian pada tindakan prasiklus anak yang berkemampuan berkembang sesuai harapan dari tidak ada menjadi 4 orang anak pada siklus I, dan menjadi 6 orang anak pada siklus II. Terakhir dapat dilihat pula anak yang berkemampuan berkembang sangat baik ( pada tindakan prasiklus dan siklus I tidak ada anak yang terlihat, sedangkan pada siklus II menjadi meningkat yaitu 4 orang anak.

\section{PEMBAHASAN}

Kegiatan tindakan siklus I diketahui bahwa ada beberapa kendala yang menyebabkan berbicara anak kurang berkembang.Penyebab dari kendala tersebut adalah, kurangnya motivasi untuk anak dalam meningkatkan kemampuan berbicara, kemudian media yang digunakan tidak terlalu kreatif untuk memancing anak untuk tidak mau berbicara. Menurut Tarigan (Safangati (2015:4) sebuah gambar atau rangkaian beberapa gambar merupakan sarana ampuh untuk memancing, mendorong atau memotivasi seorang anak berbicara..Oleh sebab itu, ketika kegiatan berlangsung ataupun sebelum melakukan kegiatan guru harus memberikan dorongan kepada anak agar anak termotivasi. Peningkatan kemampuan anak ini terjadi karena sebelum kegiatan pembelajaran anak terlebih dahulu diberi motivasi oleh guru, kemudian disaat pembelajaran anak dikenalkan dengan berbagai cerita gambar berseri, sehingga anak akan termotivasi atau bersemangat saat melihat gambar, kemudian penasaran dengan seri lainnya sehingga menimbulkan kemauan anak untuk bertanya maupun berbicara mengemukakan ide dan pendapatnya.

Dari uraian diatas menunjukkan bahwa hasil akhir dari penelitian meningkatkan kemampuan berbicara anak melalui media gambar berseri di TK Permata Bunda pada kelompok B dinyatakan berhasil karena berdasarkan indikator kinerja, keberhasilan dinyatakan berhasil apabila sudah mencapai $75 \%$ dari seluruh anak mendapatkan kategori bintang 3-4.

\section{KESIMPULAN}

Berdasarkan hasil penelitian dan pembahasan, maka diperoleh kesimpulan yaitu peningkatan kemampuan berbiacara anak dapat dilakukan dengan menggunakan media gambar berseri. Karena rangkaian beberapa gambar merupakan sarana ampuh untuk memancing, mendorong dan memotivasi seorang anak berbicara. 


\section{DAFTAR PUSTAKA}

Dimyati, Jhoni. 2013. Metodologi Penelitian dan Aplikasinya Pada Pendidikan Anak Usia Dini. Jakarta: Kencana Prenatal Media Group

Dhieni, Nurbiana dkk. 2005. Metodelogi Pengembangan Bahasa. Jakarta: Universitas Terbuka

Hairuddin, dkk. 2007. Pembelajaran Bahasa Indonesia. Jakarta: Direktorat Jenderal Pendidikan Tinggi

Kementrian Pendidikan dan Kebudayaan Republik Indonesia.2014. Peraturan Mentri Pendidikan dan Kebudayaan Republik Indonesia.Kurikulum 2013 Pendidikan Anak Usia Dini. Nomor 146.

Sadiman, Arief, dkk.2002. Media Pendidikan: Pengertian pengembangan dan pemanfaatanya. Jakarta: PT. Raja Grafindo Pustaka

Safangati, Sri. 2015. Peningkatan Kemampuan Berbicara Melalui Media Gambar Berseri pada Kelompok A di TK ABA Barahan Galur Kulon Progo. Skripsi: Universitas Negeri Yogyakarta (Online), (http://eprints.uny.ac.id)

Sanjaya, Wina. 2009. Penelitian Tindakan Kelas. Jakarta: Kencana Prenada Media Group

Surna, I Nyoman dan Olga, D Panderiot. 2004. Psikologi Pendidikan I. Jakarta: PT Gelora Aksara Permata

Trianto. 2009, Model Pembelajaran Inovatif Berorientasi Kontruktivistik. Jakarta: Kencana Prenada Media Group

Yus, Anita. 2014. Model Pendidikan Anak Usia Dini. Jakarta: Kencana Prenada Media Group

Zaman, Badrun, dkk, 2007. Media dan Sumber Belajar TK. Jakarta: Universitas Terbuka 